\title{
Pengaruh Lama Fermentasi Pada Kombinasi Liter Ayam, Serbuk Kayu Pinus dan Eceng Gondok Terhadap Kualitas Pupuk Organik
}

(The Effect of Storage Time on The Combination of Chicken Litter, Pine Sawdust, and Water Hyacinth on The Quality of Organic Fertilizer)

\author{
Umar Azhari ${ }^{1}$, Allaily ${ }^{1 *}$, M. Aman Yaman ${ }^{1}$ \\ ${ }^{1}$ Program Studi Peternakan, Fakultas Pertanian, Universitas Syiah Kuala \\ *Corresponding author: allaily@unsyiah.ac.id
}

\begin{abstract}
Abstrak. pupuk organik adalah pupuk yang berasal dari tanaman atau hewan yang terdiri atas suatu bahan organik yang sudah melalui proses rekayasa, dapat berbentuk padat atau cair yang digunakan sebagai penyuplai bahan organik untuk memperbaiki sifat biologi, kimia, dan fisik tanah. Pupuk organik yang berasal dari pupuk kandang terdapat unsur hara yang bervariasi tergantung pada jenis ternak, usia ternak, kesehatan ternak dan makanan ternak. Pupuk kandang adalah pupuk organik yang manghasilkan C-organik, N-total yang tinggi dan mudah terdekomposisi. Penelitian ini menggunakan Rancangan Acak Lengkap (RAL) yang terdiri atas 4 (empat) perlakuan yaitu $\mathrm{P} 0=0$ minggu fermentasi, $\mathrm{P} 1=2$ minggu fermentasi, $\mathrm{P} 2=4$ minggu fermentasi, dan $\mathrm{P} 3=6$ minggu fermentasi, dengan 4 (empat) kali ulangan. Data yang diperoleh dianalisis menggunakan ANOVA (Analysis of Variance), jika terdapat perbedaan yang nyata maka dilanjutkan dengan uji Uji Beda Nyata Terkecil (BNT). Hasil penelitian menunjukan bahwa lama fariasi tidak berpengaruh nyata $(\mathrm{P}>0,05)$ terhadap kualitas pupuk organik.
\end{abstract}

Kata kunci: Eceng Gondok,, Lama Fermentasi, Liter Ayam, Pupuk Organic, Serbuk Kayu Pinus

Abstract. organic fertilizer is fertilizer derived from plants or animals consisting of an organic material that has gone through an engineering process, can be in solid or liquid form which is used as a supplier of organic matter to improve the biological, chemical and physical properties of the soil. Organic fertilizers derived from manure contain nutrients that vary depending on the type of livestock, age of livestock, health of livestock and fodder. Manure is an organic fertilizer that produces high organic $\mathrm{C}, \mathrm{N}$-total and is easy to decompose. This study used a Completely Randomized Design (CRD) consisting of 4 (four) treatments, namely P0 $=0$ weeks of fermentation, $\mathrm{P} 1=2$ weeks of fermentation, $\mathrm{P} 2=4$ weeks of fermentation, and P3 $=6$ weeks of fermentation, with 4 (four) replications. The data obtained were analyzed using ANOVA (Analysis of Variance), if there is a significant difference then proceed with the Least Significant Difference Test (BNT). The results showed that the length of variation had no significant effect $(\mathrm{P}>0.05)$ on the quality of organic fertilizer.

Keywords: Liter of Chicken, Long Fermentation, Organic Fertilizer, Pine Wood Powder, Water Hyacinth

\section{PENDAHULUAN}

Pupuk organik adalah bahan yang terbuat dari campuran materi organik baik berupa sisa hijauan maupun limbah buangan ternak yang telah melewati proses Komposting (fermentasi anaerob) dimana terlibat aktifitas mikroorganisme. Pengomposan adalah proses penghancuran bahan organik oleh aktifitas berbagai jenis mikroorganisme didalam suatu lingkungan tertentu, dengan hasil akhir berupa produk yang dapat dimanfaatkan bagi kesuburan tanah (Komarayati, 1996). Bahan organik yang dapat didekomposisi adalah liter yang merupakan limbah lapisan lantai pemeliharaan ayam yang disusun oleh sekam, serbuk kayu, termasuk serbuk kayu pinus.

Permasalahan utama dari kualitas pupuk organik sangat ditentukan oleh bahan-bahan yang digunakan termasuk bahan limbah seperti bahan penyusun liter ayam. Pemanfaatan dan pengolahan liter ayam menjadi kompos perlu dilakukan agar tidak mencemari lingkungan. Liter bekas pakai merupakan salah satu limbah peternakan ayam yang telah tercampur dengan feses, urine ayam dan biasanya terdiri dari serbuk gergaji, sekam atau bahan lunak lainnya. Serbuk gergaji mengandung nisbah $\mathrm{C} / \mathrm{N}$ yang cukup tinggi, untuk menurunkan nisbah $\mathrm{C} / \mathrm{N}$ tersebut, maka dilakukan perlakuan yaitu melalui proses penghancuran yang dibantu oleh mikroorganisme. 
Di Indonesia sendiri limbah liter masih jarang dimanfaatkan sebagai bahan pupuk kandang, padahal limbah liter banyak mengandung bahan organik yang dapat dimanfaatkan untuk menyuburkan tanah dan tumbuh-tumbuhan. Kandungan bahan organik yang terdapat pada liter ayam tersebut dapat digunakan sebagai sebuah media untuk mikroba pengurai sebagai bahan nutrisinya. Tetapi liter bekas pakai tanpa dilakukan pengolahan terlebih dahulu belum sepenuhnya dapat terurai menjadi bahan anorganik yang dapat diserap tumbuhan.

Selain limbah liter ayam, bahan organik lainnya yang dapat dijadikan sebagai unsur penyubur tanah adalah kompos eceng gondok. Menurut Muhtar (2008) tanaman eceng gondok mempunyai sifat-sifat yang baik antara lain menyerap logam-logam berat, senyawa sulfide, mengandung protein lebih dari $11,5 \%$ dan mengandung selulosa yang lebih tinggi dari non selulosanya seperti lignin, abu, lemak, dan zat-zat lain. Kompos eceng gondok juga memiliki kandungan N, P, K yang dibutuhkan oleh tanaman.

Kayu pinus merupakan jenis kayu yang menghasilkan limbah yang dimanfaatkan sebagai alas kandang usaha peternakan unggas. Namun penggunaan alas kandang berbahan pinus mengalami penguraian dengan waktu yang sangat lama. Disisi lain, penanganan liter ayam yang kurang tepat dapat menimbulkan berkembangbiaknya berbagai mikroorganisme patogen dan organisme vektor penyakit seperti lalat (Suyono dan Budiman, 2010). Hal tersebut menjadi masalah yang perlu diupayakan melalui pengolahan lebih baik dengan mengggunakan stater (inokulan) kompos. Melihat potensi serbuk kayu pinus sulit untuk terurai dan eceng gondok dapat dijadikan sebagai bahan baku pembuatan pupuk organik maka perlu dilakukan penelitian terkait dengan waktu yang dibutuhkan atau lama pemeraman menjadi pupuk organik.

\section{METODE PENELITIAN}

Penelitian ini telah dilaksanakan di Laboratorium Lapangan Peternakan (LLP) Fakultas Pertanian Universitas Syiah Kuala, Banda Aceh. Kegiatan penelitian telah dilaksanakan pada bulan November 2020.

\section{MATERI DAN METODE}

\section{Alat dan Bahan}

Ada juga bahan yang digunakan adalah liter ayam (kayu sembarang), ketam pinus dan eceng gondok.

Alat yang digunakan pada penelitian ini adalah $\mathrm{pH}$ meter, thermometer, timbangan, wadah, sekop dan kantong plastik

\section{Proses Pembuatan Pupuk Organik}

Beberapa bahan yang digunakan yaitu litter ayam 55\%, serbuk kayu pinus $30 \%$ dan eceng gondok $15 \%$ dicampurkan dan dibagikan sebanyak $5 \mathrm{~kg}$ pada masing-masing sampel lalu diberikan Em4 sebanyak 2\% yang sudah dilarutkan dengan 1 liter air ke setiap sampel. Kemudian setiap sampel dimasukkan ke dalam kantong plastik lalu diikat dengan kuat sampai tidak tersisa oksigen di dalam kantong plastik yang dimana pengomposan dilakukan secara anaerob. Setiap perlakuan terdapat $5 \mathrm{~kg}$ sampel dan dilakukan sebanyak 4 (empat) kali ulangan. Selanjutnya, sampel difermentasi sesuai dengan perlakuan (0 minggu, 2 minggu, 4 minggu dan 6 minggu) setelah itu dilakukan analisa.

\section{Rancangan Penelitian}

Penelitian ini menggunakan rancangan acak lengkap (RAL) yang terdiri 4 (empat) pelakuan, yaitu $\mathrm{P}_{0}=0$ minggu fermentasi, $\mathrm{P}_{1}=2$ minggu fermentasi, $\mathrm{P} 2=4$ minggu fermentasi, 
$\mathrm{P}_{3}=6$ minggu fermentasi, setiap perlakuan diulang sebanyak 4 kali sehingga terdapat 16 unit percobaan dengan penambahan $2 \%$ Em4 pada masing-masing sampel.

\section{Uji Derajat Keasaman (pH) Pupuk Organik}

Pengukuran $\mathrm{pH}$ dilakukan menggunakan $\mathrm{pH}$ meter. Plastik berisi kompos dibuka , kemudian dimasukkan $\mathrm{pH}$ meter kepermukaan pupuk organik selama 10 detik selanjutnya catat angka yang ditunjukkan oleh $\mathrm{pH}$ meter. Pengukuran dilakukan dari minggu ke $0,2,4$ dan minggu ke 6 pada masing-masing sampel.

\section{Uji Rasio C/N Pupuk Organik}

Pengukuran rasio $\mathrm{C} / \mathrm{N}$ dilakukan di laboratorium ilmu tanah Fakultas Pertanian Universitas Syiah Kuala, Banda Aceh, yang dimana pengujian telah dilakukan oleh laboran Laboratorium Ilmu Tanah. Lalu dihitung dan dicatat data hasil dari pengujian laboratorium.

\section{Uji Temperatur Pupuk Organik}

Pengukuran suhu dilakukan menggunakan termometer digital. Dengan cara ikatan kantong plastik dibuka kemudian hidupkan termometer sampai terlihat angka $0^{\circ} \mathrm{C}$, lalu masukkan termometer ke permukaan pupuk organik tunggu selama 10 detik. Kemudian catat suhu yang ditunjukkan pada termometer. Perlakuan ini dilakukan pada minggu ke-0,2,4 dan minggu ke 6 pada masing-masing sampel.

\section{Uji Kelembaban Pupuk Organik}

Uji kelembaban dilakukan menggunakan soil tester dengan cara ikatan kantong plastik dibuka kemudian masukkan soil tester kepermukaan pupuk organik. Selanjutnya catat angka yang ditunjukkan oleh alat pengukur. Pengukuran dilakukan pada minggu ke-0, 2, 4 dan 6 pada masing-masing sampel.

\section{Analisa Statistik}

Data yang diperoleh dianalisis menggunakan analisis sidik ragam (analysis of variance/ANOVA) dan jika terdapat perbedaan yang nyata dilanjutkan dengan uji Beda Nyata Terkecil (BNT) (Steel dan Torrie, 1995).

\section{HASIL DAN PEMBAHASAN}

\section{Nisbah C/N Pupuk Organik}

Berdasarkan hasil penelitian yang didapat diketahui perbedaan lama penyimpanan terhadap pupuk organik mengandung kombinasi serbuk kayu pinus, liter ayam dan eceng gondok dengan level bioaktivator $2 \%$ tidak menyebabkan berbeda nyata terhadap rasio $\mathrm{C} / \mathrm{N}$ pupuk organik . Hasil nisbah atau rasio $\mathrm{C} / \mathrm{N}$ pupuk organik mengandung kombinasi serbuk kayu pinus, liter ayam dan eceng gondok dengan level bioaktivator $2 \%$ yang disimpan sampai 6 minggu berkisar antara 44,13-53,10. Dilihat dari keseluruh hasil rasio $\mathrm{C} / \mathrm{N}$ yang diperoleh pada setiap perbedaan lama penyimpan sampai 6 minggu belum sesuai dengan C/N SNI, nisbah C/N kompos yaitu 10-20. Nilai $\mathrm{C} / \mathrm{N}$ dari pupuk organik yang masih tinggi menunjukkan bahwa bahan organik belum terdekomposisi sempurna.

Rasio $\mathrm{C} / \mathrm{N}$ bahan organik merupakan gambaran perbandingan kandungan unsur karbon (C) terhadap banyaknya kandungan unsur nitrogen yang ada pada suatu bahan organik yang digunakan dalam pembuatan pupuk organik. Mikroorganisme membutuhkan karbon dan nitrogen untuk aktivitas hidupnya. Jika rasio $\mathrm{C} / \mathrm{N}$ tinggi, aktivitas biologi mikroorganisme akan 
berkurang, diperlukan beberapa siklus mikroorganisme untuk mendegradasi material pupuk organik sehingga diperlukan waktu yang lama untuk pengomposan dan dihasilkan mutu yang lebih rendah, jika rasio $\mathrm{C} / \mathrm{N}$ terlalu rendah kelebihan nitrogen yang tidak dipakai oleh mikroorganisme tidak dapat diasimilasi dan akan hilang melalui volatisasi sebagai amoniak atau terdenitrifikasi (Djuarnani, 2005). Lamanya waktu yang dibutuhkan dalam proses pemeraman tersebut sangat tergantung pada sifat fisik dan sifat kimia bahan penyusun pupuk organik.

Tabel 1. Hasil nisbah $\mathrm{C} / \mathrm{N}$ pupuk organik kombinasi media campuran liter ayam, limbah serbuk kayu pinus, limbah eceng gondok

\begin{tabular}{|c|c|c|c|c|}
\hline \multirow{2}{*}{ Ulangan } & \multicolumn{4}{|c|}{ Perlakuan } \\
\hline & $\mathrm{P} 0$ & $\mathrm{P} 1$ & P2 & P3 \\
\hline I & 42,34 & 46,05 & 39,65 & 48,46 \\
\hline II & 39,19 & 56,22 & 54,96 & 62,02 \\
\hline III & 44,28 & 46,37 & 55,83 & 53,25 \\
\hline IV & 32,29 & 52,86 & 51,62 & 53,90 \\
\hline Rerata & $44,13 \pm 3,90$ & $53,10 \pm 9,77$ & $49,93 \pm 5,49$ & $47,67 \pm 10,29$ \\
\hline & $\begin{array}{l}\text { P0 }=\text { Ferment } \\
\text { P1 }=\text { Ferment } \\
\text { P2 }=\text { Ferment } \\
\text { P3 }=\text { Ferment }\end{array}$ & $\begin{array}{l}\operatorname{ggu} \\
\text { ggu } \\
\text { ggu } \\
\text { ggu }\end{array}$ & & \\
\hline
\end{tabular}

\section{Derajat Keasaman (pH) Pupuk Organik}

Berdasarkan hasil analisis sidik ragam dapat diketahui bahwa perbedaan lama pemeraman sampai 6 minggu pada kombinasi media campuran liter ayam berbasis limbah serbuk kayu pinus dan eceng gondok tidak berpengaruh nyata $(\mathrm{P}>0,05)$ terhadap derajat keasaman $\mathrm{pH}$ pupuk organik. Rerata derajat keasaman $\mathrm{pH}$ pupuk organik berkisar antara 3,875 sampai dengan 6,875. Penurunan $\mathrm{pH}$ pupuk organik dapat disebabkan oleh lama waktu pemeraman pada proses komposting. Hasil kompos dalam kondisi asam maka kemungkinan kecenderungan kompos belum matang dan menunjukkan adanya aktivitas bakteri dalam menguraikan bahan-bahan organik seperti selulosa, karbohidrat, protein dan lignin menjadi asam-asam organik (Wahyono et al, 2011).

Tabel 2. Rataan derajat keasaman (ph) pupuk organik kombinasi media campuran liter ayam limbah serbuk kayu pinus, limbah eceng gondok

\begin{tabular}{|c|c|c|c|c|c|}
\hline \multirow{2}{*}{ Ulangan } & \multicolumn{4}{|c|}{ Perlakuan } & \multirow{2}{*}{ Jumlah } \\
\hline & P0 & P1 & $\mathrm{P} 2$ & P3 & \\
\hline $\mathrm{I}$ & 4,00 & 6,80 & 6,80 & 6,90 & 24,50 \\
\hline II & 3,60 & 6,70 & 6,90 & 6,80 & 24,00 \\
\hline III & 4,00 & 6.80 & 6.50 & 6,90 & 24.20 \\
\hline IV & 3,90 & 6,50 & 5,70 & 6,90 & 23,00 \\
\hline Jumlah & 15,50 & 26,80 & 25,90 & 27,50 & 95,70 \\
\hline Rerata & $3,875 \pm 1,42$ & $6,7 \pm 1,60$ & $6,475 \pm 0,1,38$ & $6,875 \pm 1,33$ & \\
\hline $\begin{array}{r}\text { Keterangan: } \mathrm{P} 0= \\
\mathrm{P} 1 \\
\mathrm{P} 2 \\
\mathrm{P} 3\end{array}$ & $\begin{array}{l}\text { nentasi } 0 \text { Mingg } \\
\text { nentasi } 2 \text { Mingg } \\
\text { nentasi } 4 \text { Mingg } \\
\text { nentasi } 6 \text { Mingg }\end{array}$ & & & & \\
\hline
\end{tabular}


pH material pupuk organik bersifat asam di awal pengomposan karena bakteri pembentuk asam akan menurunkan $\mathrm{pH}$ sehingga pupuk organik bersifat lebih asam. Selanjutnya mikroorganisme mulai mengubah nitrogen anorganik menjadi amoniak sehingga pH meningkat cepat menjadi basa (Marlina, 2009). pH akan meningkat menjadi basa, apabila sudah terjadi pembentukan amonia (Baharuddin et al, 2009).

Derajat keasaman pupuk organik sangat dipengaruhi oleh kadar air material organik yang terkandung, aktivitas bakteri dalam proses pengomposan dan jenis bakteri yang aktif. Berdasarkan nilai $\mathrm{pH}$ kompos maka dapat dikenali jenis bakteri yang aktif, yaitu $\mathrm{pH} 2$ jenis bakteri Acidofilik, $\mathrm{pH} 3$ bakteri Nesofilik atau Neutorfilik dan $\mathrm{pH}$ basa maka yang hidup adalah bakter Basofilik (Beales, 2004).

\section{Kelembaban Pupuk Organik}

Berdasarkan hasil analisis sidik ragam dapat diketahui bahwa lama pemeraman pada kombinasi media campuran liter ayam berbasis limbah serbuk kayu pinus dan eceng gondok tidak berpengaruh nyata $(\mathrm{P}>0,05)$ terhadap kelembaban pupuk organik. Rerata kelembaban pupuk organik berkisar antara 23,75\% sampai dengan 37,00\%. Pada penelitian ini dapat dilihat dari rata-rata kelembaban tidak sesuai dengan kisaran optimum.Yuliarti (2019) menyatakan kelembaban yang baik pada pupuk organik berkisar 40 - 60\%.. kelembaban di bawah 40\%, akan terjadi penurunan aktivitas mikroba dan akan lebih rendah lagi pada kelembaban $15 \%$.

Tabel 3. Rataan kelembaban pupuk organik kombinasi media campuran liter ayam limbah serbuk kayu pinus, limbah eceng gondok

\begin{tabular}{|c|c|c|c|c|c|}
\hline \multirow{2}{*}{ Ulangan } & \multicolumn{4}{|c|}{ Perlakuan } & \multirow{2}{*}{ Jumlah } \\
\hline & P0 & $\mathrm{P} 1$ & $\mathrm{P} 2$ & P3 & \\
\hline I & 80,00 & 90,00 & 80,00 & 80,00 & 330,00 \\
\hline II & 5,00 & 8,00 & 8,00 & 25,00 & 46,00 \\
\hline III & 5,00 & 5,00 & 25,00 & 38,00 & 73,00 \\
\hline IV & 5,00 & 5,00 & 5,00 & 5,00 & 20,00 \\
\hline Jumlah & 95,00 & 108,00 & 118,00 & 148,00 & 469,00 \\
\hline Rerata & $23,75 \pm 37,50$ & $27 \pm 42,02$ & $29,5 \pm 34,80$ & $37,00 \pm 31,72$ & \\
\hline Keteranga & $\begin{array}{l}=\text { Fermentasi } 0 \mathrm{~N} \\
=\text { Fermentasi } 2 \mathrm{M} \\
=\text { Fermentasi } 4 \mathrm{M} \\
=\text { Fermentasi } 6 \mathrm{M}\end{array}$ & & & & \\
\hline
\end{tabular}

Rendahnya tingkat kelembaban pada penelitian ini diduga karena kurangnya lama waktu pemeraman dan adanya peningkatan aktivitas mikroorganisme pada pupuk, namun tidak diimbangi dengan kapasitas dari bahan pupuk tersebut dimana limbah eceng gondok masih belum terurai, maka dibutuhkan waktu pemeraman yang lebih lama lagi agar bahan organik pada saat proses pengomposan terurai sempurna, dikarenakan serbuk pinus memiliki struktur fisik yang masih keras. Pendapat ini diperkuat dengan penelitian yang dilakukan oleh Kurniawan et al. (2013) yang menyatakan bahwa semakin meningkatnya starter maka jumlah mikroorganisme yang ada di dalam pupuk akan meningkat pula namun hal ini tidak diimbangi dengan peningkatan kapasitas dari bahan pupuk tersebut sebagai sumber makanan bagi mikroorganisme.

\section{Kelembaban Pupuk Organik}


Berdasarkan hasil analisis sidik ragam dapat diketahui bahwa lama pemeraman pada kombinasi media campuran liter ayam berbasis limbah serbuk kayu pinus dan eceng gondok tidak berpengaruh nyata $(\mathrm{P}>0,05)$ terhadap derajat temperatur pupuk organik. Rerata temperatur pupuk organik berkisar antara $27,7^{\circ} \mathrm{C}$ sampai dengan $33,22^{\circ} \mathrm{C}$. dalam penelitian ini lama pemeraman kombinasi media campuran liter ayam berbasis limbah serbuk kayu pinus dan eceng gondokbelum mencapai suhu yang sesuai dalam SNI 19-7030-2004 (BSN 2004). Rendahnya suhu kompos diduga disebabkan karena jumlah limbah pada proses pengomposan tidak cukup memberikan proses insulasi panas (Widarti et al., 2015).

Tabel 1. Rataan temperatur pupuk organik kombinasi media campuran liter ayam limbah serbuk kayu pinus, limbah eceng gondok

\begin{tabular}{cccccc}
\hline \multirow{2}{*}{ Ulangan } & \multicolumn{5}{c}{ Perlakuan } \\
\cline { 2 - 5 } & P0 & P1 & P2 & P3 & \\
\hline I & 33,60 & 27,70 & 27,80 & 27,90 & 117,00 \\
II & 33,80 & 27,80 & 28,10 & 27,80 & 117,50 \\
III & 32,60 & 27,70 & 27,60 & 27,90 & 115,80 \\
IV & 32,90 & 27,60 & 27,60 & 27,30 & 115,40 \\
\hline Jumlah & 132,90 & 110,80 & 111,10 & 110,90 & 465,70 \\
\hline Rerata & $33,22 \pm 2,901$ & $27,7 \pm 2,953$ & $27,775 \pm 2,437$ & $27,725 \pm 2,074$ \\
\hline Keterangan: P0 $=$ Fermentasi 0 Minggu & & & \\
& P1 = Fermentasi 2 Minggu & & &
\end{tabular}

Pernyataan ini berhubungan dengan pendapat Yaman (2019) menyatakan bahwa proses pembuatan pupuk organik sangat tergantung pada jumlah dan jenis bahan organik yang dipergunakan serta perlakuan yang diberikan sejak persiapan sampai proses pemeraman. Lebih lanjut diperkuat oleh Pandebesie (2013) yaitu kurang tingginya suhu kompos disebabkan karena jumlah limbah yang dikomposkan tidak cukup memberikan proses insulasi panas. Peningkatan suhu diduga karena adanya aktivitas bakteri dalam proses dekomposisi bahan organik. Suhu yang berangsur menurun dikarenakan berkurangnya bahan organik yang dapat diurai oleh mikroorganisme. Pada saat kondisi suhu menurun, mikroorganisme mesofilik berkembang menggantikan mikroorganisme termofilik. Suhu mempengaruhi jenis mikroorganisme yang hidup dalam media.

Kondisi mesofilik lebih efektif saat proses pengomposan karena aktivitas mikroorganisme didominasi protobakteri dan fungi. Penurunan suhu juga mendorong pada ketidak seimbangan metabolisme dan penghentian pertumbuhan karena pengaruh sensitif terhadap beberapa proses metabolisme (Pandebesie, 2013)

\section{Kesimpulan}

\section{KESIMPULAN DAN SARAN}

Berdasarkan hasil penelitian dapat disimpulkan bahwa pengaruh lama pemeraman pada kombinasi media campuran liter ayam berbasis limbah serbuk kayu pinus dan eceng gondok terhadap kualitas pupuk organik tidak berpengaruh terhadap kualitas dan peningkatan rasio $\mathrm{C} / \mathrm{N}$ yang sesuai dengan standar yang sudah ditetapkan oleh Badan Standar Nasional Indonesia (SNI) 197030-2004. Kemungkinan utama disebabkan bahan yang digunakan pada penelitian khususnya serbuk kayu pinus masih dalam keadaan belum terdekomposisi dan memiliki tekstur 
yang solid sehingga belum bisa menghasilkan kualitas pupuk organik yang baik sehingga dibutuhkan lama pemeraman yang lebih lama lagi.

\section{Saran}

Untuk mendapatkan hasil yang lebih akurat mengenai efektifitas lama pemeraman pada kombinasi media campuran liter ayam berbasis limbah serbuk kayu pinus dan eceng gondok terhadap kualitas pupuk organik sebaiknya juga memperhatikan ukuran bahan yang terlalu besar dicacah menjadi lebih kecil dan bahan yang masih terlalu basah dikeringkan terlebih dahulu sebelum melalui proses pengomposan.

\section{DAFTAR PUSTAKA}

Komarayati, S. 1996. Pemanfaatan Serbuk gergaji Limbah Industri Sebagai Kompos. Buletin Penelitian Hasil Hutan Vol. 14 No. 9: 337-343.

Muhtar, A. 2008. Penggunaan Tanaman Eceng Gondok Sebagai Pre-Teratman Pengolahan Air Minum Pada Air Selokan Mataram. Tugas Akhir Strata-1 Teknik Lingkungan : Tugas akhir Tidak Diterbitkan. Yogyakarta : UII.

Steel, R. G. D and J. H. Torrie. 1990. Prinsip dan Prosedur Statistik. Suatu Pendekatan Biometrik. Alih Bahasa Ir. B. Soemantri. Ed II. Gramedia Jakarta, Jakarta.

Djuarni, N. 2005. Cara Cepat Membuat Kompos. Agromedia Pustaka. Jakarta.

Wahyono, S., F. L. Sahwan, dan Suryanto, F. 2011. Membuat Pupuk Organik Granul dari Aneka Limbah. PT. Argomedia Pustaka. Jakarta.

Marlina, E. T. 2009. Biokonservasi Limbah Industri Peternakan. Bandung: Universitas Padjajaran PRESS.

Beales, N. 2004. Adaptation of Microorganisms to Cold Temperatures, Weak Acid Preservatives, Low pH, and Osmotic Stress: A Review. Comprehensive Reviews in Food Science and Food Safety, 3, 1-20.

Kurniawan, D. Kumalaningsih, S. Mayang, N. S. S. 2009. Pengaruh Volume Penambahan Effective Microorganism 4 (EM4) 1\% dan Lama Fermentasi Terhadap Kualitas Pupuk Bokashi dari Kotoran Kelinci dan Limbah Nangka. Jurnal Industrial. Fakultas Teknik Pertanian Universitas Brawijaya. Vol 2 No. 1: 57 - 66.

Widarti, et al. 2015. Pengaruh Rasio C/N Bahan Baku Pada Pembuatan Kompos dari Kubis Dan Kulit pisang. Universitas Mulawarman. Samarinda.

Yaman, M. A. 2019. Teknologi Penanganan, Pengolahan Limbah Ternak dan Hasil Samping Peternakan. Syiah Kuala University Press.

Pandebesie, E.S. 2013.Pengaruh Penambahan Sekam Pada Proses Pengomposan Sampah Domestik. Jurnal Lingkungan Tropis, 2013, 6(1), 31 - 40. 